Racing Romance 



\section{Racing Romance}

Love, Power, and Desire among Asian American/White Couples

KUMIKO NEMOTO 
Library of Congress Cataloging-in-Publication Data

Nemoto, Kumiko, 1970-

Racing romance : love, power, and desire among Asian American / white couples / Kumiko Nemoto.

p. $\quad \mathrm{cm}$.

Includes bibliographical references and index.

ISBN 978-0-8135-4532-5 (hardcover : alk. paper)

ISBN 978-0-8135-4533-2 (pbk. : alk. paper)

1. Interracial marriage-United States. 2. Interracial dating-United States.

3. Asian Americans-Psychology. 4. Asian Americans-Race identity.

5. Race awareness. 6. Race relations. I. Title.

HQ1031.N45 2009

306.84'608995073—dc22

A British Cataloging-in-Publication record for this book is available from the British Library.

Copyright (C) 2009 by Kumiko Nemoto

All rights reserved

No part of this book may be reproduced or utilized in any form or by any means, electronic or mechanical, or by any information storage and retrieval system, without written permission from the publisher. Please contact Rutgers University Press, 100 Joyce Kilmer Avenue, Piscataway, NJ 08854-8099. The only exception to this prohibition is "fair use" as defined by U.S. copyright law.

Visit our Web site: http://rutgerspress.rutgers.edu

Manufactured in the United States of America

Composition: Jack Donner, BookType 
For my mother 
